JST 8 (1) (2019)
JURNAL SENI TARI
Terakreditasi SINTA 5
Teurnal.unnes.ac.id/siu/index.php/ist

\title{
Analisis Gaya Slangit Tari Topeng Tumenggung di Desa Slangit Cirebon
}

\author{
Nur Indah Hidayani ${ }^{1}$, Restu Lanjari ${ }^{2}$ \\ Jurusan Sendratasik, Fakultas Bahasa dan Seni, Universitas Negeri Semarang, Indonesia
}

\begin{tabular}{l} 
Info Artikel \\
\hline Sejarah Artikel \\
Diterima : 28 Mei 2019 \\
Disetujui : 22 Juni 2019 \\
Dipublikasikan : 23 Juli \\
2019
\end{tabular}

Keywords:

Mask Dance; Dance Style;

presentation form.

\begin{abstract}
Abstrak
Tari Topeng Tumenggung merupakan salah satu Tari Topeng Cirebon yang berada pada urutan keempat mengisahkan tentang Tumenggung Magangdiraja yang diutus oleh Raja Bawarna untuk mencari Jinggananom yang telah lama tidak membayar upeti. Tujuan penelitian yakni menganalisis bentuk penyajian Tari Topeng Tumenggung Gaya Slangit serta menganalisis Gaya Tari Topeng Tumenggung Slangit Cirebon. Metode penelitian yang digunakan adalah kualitatif dengan menggunakan pendekatan etnokoreologi. Teknik pengumpulan data yang digunakan yakni observasi, wawancara dan dokumentasi. Teknik keabsahan data menggunakan triangulasi sumber. Hasil penelitian bentuk penyajian Tari Topeng Tumenggung Gaya Slangit meliputi gerak yang terdiri dari 3 tahap yakni dodoan, unggah tengah serta deder/kering tilu dengan iringan musikTumenggungan, Waledan, dan Barlen, adapun pola lantai yang digunakan dalam pertunjukan Tari Topeng Tumenggung Gaya Slangit tidak baku artinya setiap penari dapat mengkreasikan sendiri pola lantai saat menari. Rias yang digunakan yaitu rias korektif serta busana yang meniru atribut-atribut dari orang yang berstatus sosial tinggi seperti pemakaian kalung, dasi, dan topi, adapun properti yang digunakan yaitu Topeng Tumenggung. Tari Topeng Tumenggung Gaya Slangit Cirebon dipentaskan di ruang terbuka. Analisis gaya Tari Topeng Tumenggung Gaya Slangit Cirebon muncul melalui analisis postur, interpretasi dan kreativitas.
\end{abstract}

Tumenggung Mask Dance is one of the Cirebon Mask Dance which is in fourth place tells about Tumenggung Magangdiraja who sent by Raja Bawarna to look for Jinggananom who have not paid tribute for a long time. The purpose of this research is to analyze the presentation formof Tumenggung Mask Dance in Slangit style and analyze the style of Tumenggung Slangit Cirebon Mask Dance. The research method used qualitative with etnochoreology approach. Data collection techniques used observation, interviews and documentation. Data validity used source triangulation. The results show that the form of Tumenggung Mask Dance Style Slangit include motion consisting of 3 stages namely dodoan, unggah tengah and deder/kering tilu with Tumenggungan, Waledan, and Barlen music, and floor design used in Tumenggung Mask Dance performances Slangit style can change it's mean each dancer can create his own floor design when dancing. Makeup used is corrective makeup and costume like imitatethe attributes of people with high social status such as the use of necklace, tie and hats with Tumenggung mask for the property dance. Tumenggung Mask Dance of Slangit Style Cirebon is performed in an open space. Analysis style of Tumenggung Mask Dance appeared with posture analysis, interpretation and creativity.

(C) 2019 Universitas Negeri Semarang

\footnotetext{
${ }^{\square}$ Alamat korespondensi:

Gedung B2 Kampus Sekaran, Gunungpati, Semarang, 50229

Email : 1. seasoniiindah@vahoo.co.id
}

2. restulaniari1961@mail.unnes.ac.id

ISSN 2503-2585




\section{PENDAHULUAN}

Tari Topeng Cirebon tumbuh dan berkembang pada masa pemerintahan Raja Jenggala di Jawa Timur yaitu Prabu Panji Dewa pada abad 10-11 M, kemudian Tari Topeng masuk ke Cirebon dan mengalami perpaduan dengan kesenian rakyat setempat seperti Tarling, Wayang Kulit, dan Gamelan. Pada tahun 1479-1568, Cirebon menjadi pusat penyebaran agama Islam yang dipimpin oleh Syekh Syarif Hidayatullah sebagai Sultan Cirebon bekerjasama dengan Sunan Kalijaga memfungsikan Tari Topeng dan 6 jenis kesenian lainnya seperti Wayang Kulit, Gamelan Renteng, Brai, Angklung, Reog dan Berokan sebagai bagian dari upaya penyebaran agama Islam.

Tari Topeng Cirebon kemudian berkembang, sehingga memperoleh dan memiliki bentuk penyajian yang spesifik, yang selanjutnya dikenal dengan istilah Topeng Babakan atau Dinaan karena dalam satu babak mewakili satu karakter tertentu sesuai dengan kedok yang digunakan. Pertunjukan tari Topeng Cirebon terdiri dari 5 babak yang urutan penyajiannya terdiri dari Topeng Klana, Topeng Tumenggung, Topeng Rumyang, Topeng Samba, dan diurutan pertama ada Topeng Panji (Masunah dan Karwati 2003:31-39)

Tari Topeng Gaya Slangit diciptakan oleh dalang topeng Sudjana Ardja di Desa Slangit. Dalang Topeng Sudjana Ardja menafsirkan pertunjukan tari Topeng Cirebon dalam tiga pandangan yaitu pertumbuhan jasmani manusia dari bayi sampai dewasa, kebatinan dan keagamaan. Tari Topeng Cirebon terdiri dari lima macam tarian yang biasanya disebut dengan "Panca Wanda" atau lima macam yang terdiri dari Klana, Tumenggung, Rumyang, Samba, dan Panji pada urutan pertama.

Tari Topeng Tumenggung merupakan bentuk tarian keempat yang mengisahkan sebuah kisah kecil dari cerita Panji. Dikisahkan bahwa Tumenggung Magangdiraja diutus Raja Bawarna untuk mencari Jinggananom yang hilang dan telah lama tidak membayar upeti. Ketika bertemu dengan Jinggananom,Tumenggung
Magangdiraja meminta untuk membayar upeti namun ditolak dan terjadilah perang, Jinggananom kalah.

Tari Topeng Tumenggung Gaya Slangit Cirebon hingga kini masih dilestarikan oleh salah satu sanggar yakni Sanggar Langgeng Saputra. Sanggar Langgeng Saputra dikelola oleh Bapak Sanija Wijaya selaku keturunan dari Alm Ardja. Tari Topeng Cirebon seiring dengan perkembangan zaman mengalami perbedaan khususnya pada Tari Topeng Tumenggung Gaya Slangit Cirebon yang terlihat jelas pada pemakaian kostumnya serta durasi menari.

Peneliti memilih Tari Topeng Tumenggung Gaya Slangit untuk diteliti mengenai gaya dan bentuk penyajian Tari Topeng Tumenggung Gaya Slangit di Cirebon dengan berbagai alasan dan pertimbangan seperti diketahui bahwa Tari Topeng yang ada di Cirebon berjumlah lima namun hanya Tari Topeng Tumenggung yang berbeda dengan tari Topeng Panji, Topeng Samba, Topeng Rumyang, dan Topeng Klana. Tari Topeng Tumenggung dalam kelengkapan kostum tidak menggunakan sobrah hanya menggunakan topi. Tari Topeng Tumenggung dipilih karena memiliki sifat dan karakter manusia yang bijaksana sehingga dapat menjadi gambaran kehidupan manusia yang lebih baik, selain itu dalam setiap event atau acara di Cirebon Tari Topeng Tumenggung Gaya Slangit ini jarang dipentaskan atau dilombakan sehingga peneliti memilih Tari Topeng Tumenggung Gaya Slangit Cirebon dengan menganalisis bentuk penyajian dan gaya agar tarian ini dapat dikenal oleh masyarakat luas khususnya masyarakat Cirebon.

Bentuk penyajian dalam tari mempunyai pengertian cara penyajian atau cara menghidangkan suatu tari secara menyeluruh meliputi unsur-unsur atau elemen pokok dan pendukung tari. Elemen-elemen itu ialah gerak tari, desain lantai, tata rias, kostum, tempat pertunjukan, dan musik/iringan (Soedarsono, 1978:23).

Jazuli (2016:60) mengatakan bahwa tata rupa kelengkapan sajian tari meliputi gerak, musik, tema, tata busana, 
tata rias, tempat pentas, tata lampu/cahaya, dan properti. Penelitian mengacu pada teori Jazuli yang mengatakan bahwa bentuk penyajian dapat diihat melalui gerak, musik, tema, tata busana, tata rias, tempat pentas, tata lampu/cahaya, dan property.

Gaya secara kontekstual dapat tersusun dari simbol, bentuk, dan orientasi nilai (tradisi) yang mendasari tari (Royce dalam Jazuli 2016:47). Masunah dan Karwati (2003:39) menjelaskan, istilah gaya merupakan ciri khas yang selalu berulang ketika penari tampil. Gaya individu biasanya dipengaruhi oleh interpretasi dan kreativitas individu serta postur atau wanda seseorang. Gaya individu ini dapat dijadikan pula sebagai gaya daerah atau sebaliknya. Interpretasi dapat dilihat melalui karakter peran Tumenggung yang ditarikan penari. Kreativitas penari yang terlihat pada berbagai variasi gerak serta susunan sajian tarinya dan postur atau wanda yang dapat dilihat melalui cara penari menarikan Tari Topeng Tumenggung Gaya Slangit Cirebon khususnya dalam pengolahan tenaga, ruang dan waktu.

\section{METODE}

Metode penelitian yang dianggap paling tepat dalam penelitian ini yaitu metode kualitatif dengan pendekatan etnokoreologi. Analisis data yang dikumpulkan dari narasumber untuk memperoleh data dilakukan melalui observasi, wawancara dan dokumentasi.

Data kualitatif merupakan sumber dari deskripsi yang luas dan berlandasan kokoh serta memuat penjelasan tentang proses-proses yang terjadi dalam lingkup setempat (Miles dan Huberman dalam terjemahan Rohidi 2007:1).

Lokasi penelitian dilaksanakan di Sanggar Langgeng Saputra Cirebon yang beralamat di Desa Slangit, Kecamatan Klangenan, Kabupaten Cirebon. Sasaran penelitian meliputi bentuk penyajian dan analisis Gaya Slangit Tari Topeng Tumenggung Cirebon. Subjek penelitian yaitu pimpinan Sanggar Langgeng Saputra, nayaga dan penari Tari Topeng Tumenggung Gaya Slangit Cirebon.

Penelitian ini menggunakan tiga teknik pengumpulan data yaitu observasi, wawancara dan dokumentasi. Observasi dilakukan empat kali yang pertama yaitu observasi lokasi Sanggar Langgeng Saputra pada tanggal 13 Mei 2017, yang kedua pada saat persiapan pertunjukan Tari Topeng Tumenggung Gaya Slangit Cirebon pada tanggal 10 September 2017, yang ketiga pada saat pertunjukan Tari Topeng Tumenggung Gaya Slangit Cirebon tanggal 23 September 2017, dan yang keempat setelah pertunjukan Tari Topeng Tumenggung Gaya Slangit Cirebon tanggal 24 September 2017.

Wawancara dilakukan empat kali dengan narasumber yang berbeda. Wawancara pertama dilakukan di Balai Desa Slangit Cirebon pada tanggal 13 Mei 2017 kepada Bapak Anjoyo selaku Kuwu di Desa Slangit Cirebon, pembahasan wawancara mengenai letak geografis dan demografis Desa Slangit Cirebon, kemudan dilanjutkan dengan wawancara di Sanggar Langgeng Saputra kepada Bapak Sanija Wijaya selaku pimpinan Sanggar Langgeng Saputra, pembahasan wawancara mengenai mengenai latar belakang Tari Topeng Tumenggung Gaya Slangit Cirebon.

Wawancara kedua dilakukan di Sanggar Langgeng Saputra kepada Adel selaku penari Tari Topeng Tumenggung Gaya Slangit Cirebon pada tanggal 23 September 2017, pembahasan wawancara mengenai latar belakang penari, pengalaman menarikan Tari Topeng Tumenggung Gaya Slangit Cirebon, dan pengetahuan mengenai Tari Topeng Tumenggung Gaya Slangit Cirebon, kemudian dilanjutkan wawancara kepada Mas Kano selaku nayaga Tari Topeng Tumenggung Gaya Slangit Cirebon, pembahasan wawancara mengenai latar belakang pemusik, pengalaman menjadi pemusik dalam Tari Topeng Tumenggung Gaya Slangit Cirebon, dan pengetahuan mengenai notasi iringan Tari Topeng Tumenggung Gaya Slangit Cirebon. Wawancara keempat dilakukan di Sanggar Langgeng Saputra kepada bapak Sanija Wijaya selaku pimpinan Sanggar Langgeng Saputra pada tanggal 24 September 2017, pembahasan wawancara mengenai bentuk penyajian Tari Topeng Tumenggung Gaya Slangit Cirebon dan ciri khas gaya yang ada 
dalam Tari Topeng Tumenggung Gaya Slangit Cirebon.

Dokumentasi pada penelitian ini dilakukan satu kali pendokumentasian pada tanggal 23 September 2017, peneliti melakukan pendokumentasian mengenai arsip-arsip sejarah Tari Topeng Tumenggung Gaya Slangit Cirebon, video Tari Topeng Tumenggung Gaya Slangit Cirebon, notasi iringan Tari Topeng Tumenggung Gaya Slangit Cirebon.

Peneliti menggunakan 3 teknik triangulasi yaitu triangulasi sumber, teknik, dan teori. Triangulasi sumber yaitu membandingkan satu sumber dengan sumber lainnya, triangulasi teknik yaitu membandingkan teknik satu dengan yang lainnya, dan triangulasi teori yaitu membandingkan data yang diperoleh dengan teori yang digunakan.

Teknik analisis data seni adalah suatu cara bagi pencarian atau pengujian pernyataan umum tentang keterkaitan dan yang mendasari tema-tema yang membangun teori dari lapangan (Strauss dan Corbic dalam Rohidi 2011:222).

Peneliti menggunakan analisis data dari Rohidi dengan menganalisis data setelah pengumpulan data selesai kemudian dilanjutkan dengan reduksi data, kategorisasi, sistesisasi, dan membuat kesimpulan untuk menjawab rumusan masalah.

\section{HASIL DAN PEMBAHASAN}

Gambaran Umum Desa Slangit
Kabupaten Cirebon
Penelitian dilakukan di Desa
Slangit Kecamatan Klangenan
Kabupaten Cirebon Provinsi Jawa Barat. Luas wilayah Desa Slangit tercatat \pm 358 $\mathrm{Ha}$, berbatasan dengan Desa Bangodua dan Kreyo Kecamatan Klangenan. Lokasi Desa Slangit terletak dalam koordinat antara $106^{\circ} 55^{1} 50^{11}-107^{\circ} 5^{1} 45^{11}$ Bujur Timur dan $6^{\circ} 30^{1} 20^{11}-6^{\circ} 40^{1} 10^{11}$ Lintang Selatan, dengan hamparan bidang wilayahnya berada pada elevasi antara 173 - 1745 meter di atas permukaan laut (m.dpl). Durasi perjalanan yang ditempuh dari Kota Cirebon ke Desa Slangit kisaran 30 menit.

\section{Kondisi Demografi Desa Slangit Cirebon}

Desa Slangit secara fisik Secara fisik terdiri dari $27 \%$ berupa dataran, dan sekitar $63 \%$ berupa perbukitan dan gunung, dengan keadaan lahannya sekitar $78 \%$ berupa lahan kering dan sekitar 26\% lahan basah. Terbentang 2 hulu sungai, yaitu Sungai Cileungsi dan Sungai Ciherang, umumnya lebih dominan dimanfaatkan untuk sumber pengairan bagi sawah, kolam/empang, dan keperluan rumah tangga. Warga Desa Slangit sebagian besar menjadi petani $(15,33 \%)$, pedagang $(1,75 \%)$ dan buruh $(3,96 \%)$, yang bekerja pada sektor jasa dan industri masih sangat sedikit. Penduduk Desa Slangit Cirebon dalam kehidupan sehari-hari mengunakan bahasa Cirebon dan bahasa Indonesia.

\section{Sejarah Singkat Tari Topeng Cirebon} Sejarah tari Topeng Cirebon mempunyai kesamaan dengan topeng yang berkembang di daerah Jawa Tengah, Jawa Timur, Madura, dan Bali.Pertunjukannya berkembang dalam bentuk Wayang Wong, Wayang Topeng, maupun Topeng Dalang (Masunah dan Karwati 2003:4-9).

Tari Topeng Cirebon tidak hanya berkembang di Kabupaten dan Kotamadya Cirebon saja, tetapi juga terdapat di daerah lain seperti Pekandangan, Kabupaten Indramayu, Desa Beber, serta Kabupaten Majalengka. Tari Topeng Cirebon ditinjau dari sumber cerita dan karakterisasinya memiliki persamaan sehingga tarian tersebut dapat dikategorikan ke dalam satu rumpun atau genre tari Topeng Cirebon.

Tradisi Ngamen atau pertunjukan keliling oleh rombongan topeng semenjak keluar dari tradisi keraton merupakan faktor utama saling mempengaruhinya bentuk sajian pertunjukan tari Topeng Cirebon, sehingga Topeng Cirebon mempunyai kesamaan karakterisasi dan sumber cerita dengan daerah lain yang tidak terlepas dari letak geografis pesisir pantai utara yang pada masa lalu Cirebon merupakan pusat perdagangan dan pelayaran (Sulendraningrat dalam Masunah 2000:4). Pertunjukan tari 
Topeng Cirebon pada acara ngamen atau berkeliling merupakan inisiatif dari senimannya dalam mencari nafkah.

Ngamen berfungsi pula sebagai sarana untuk belajar tari Topeng Cirebon bagi anak-anak seniman. Pertunjukan tari Topeng Cirebon pada acara apresiasi seni, festival, acara kepariwisataan dan acara kedinasan, waktunya ditentukan secara terbatas oleh penyelenggara, sehingga gerak-gerak tari yang biasanya memerlukan durasi waktu yang panjang menjadi diperpendek dan dipadatkan sesuai dengan waktu yang ditentukan oleh pihak penyelenggara.

Perubahan tari Topeng Cirebon terjadipada bentuk tariannya. Pada masa lalu pertunjukan tari Topeng Cirebon ditampilkankan sehari penuh, namun saat ini pertunjukan tari Topeng Cirebon hanya ditampilkan dalam waktu singkat antara 30 menit sampai 2 jam, dengan durasi pertunjukan satu tarian 10-30 menit.

Gaya Slangit awal mulanya muncul karena diambil dari nama asal daerah pertama kali tari Topeng Cirebon Gaya Slangit dibentuk. Para dalang Topeng Cirebon pada umumnya tidak mengaitkan kata Tumenggung sebagai tokoh Tumenggung, artinya kata Tumenggung hanya dipinjam untuk menyatakan salah satu karakter tari yang gagah yang secara kebetulan tokoh Tumenggung juga berkarakter gagah.

Tari Topeng Tumenggung tidak menggambarkan tokoh tertentu, dan hanya sebagai gambaran suatu karakter, maka tari Topeng Cirebon secara umum lebih menggambarkan karakterisasi daripada cerita.Karakter tarinya dapat digolongkan menjadi karakter alusan (halus) dan gagahan (gagah) (Sanija Wijaya, wawancara 23 September 2017).

Tari Topeng Tumenggung Gaya Slangit Cirebon memiliki sifat turun temurun di daerahnya masing-masing termasuk di Desa Slangit.Sifat turun temurun inilah yang membuat tari Topeng Tumenggung Gaya Slangit Cirebon mengalami perubahan dan perkembangan tanpa merubah ragam gerak aslinya, yang berubah hanyalah mengurangi pengulangan gerak.

\section{Bentuk Penyajian}

Bentuk Penyajian dalam tari mempunyai pengertian cara penyajian atau cara menghidangkan suatu tari secara menyeluruh meliputi unsur-unsur atau elemen pokok dan pendukung tari. Elemen-elemen itu ialah gerak tari, desain lantai, tata rias, kostum, tempat pertunjukan, dan musik/iringan (Soedarsono, 1978:23).

The forms of the performances including the drama, actors, movement, sounds, make up property, floor patterns, performing stage, and audiences (Kusumastuti dan Hartono, 2017 : 1-17).

\section{Gerak}

Durasi pertunjukan Tari Topeng Tumenggung Gaya Slangit Cirebon sekitar 15 menit.Tari Topeng Tumenggung Gaya Slangit Cirebon memiliki 3 tahap yaitu tahap dodoan, unggah tengah, dan tahap deder/kering tilu. Pada bagian ragam gerak dodoan terdapat 11 ragam gerak Tari Topeng Tumenggung Gaya Slangit Cirebon yang terdiri dari pasangan, sebrakan, mincig putar gleyong, adeg-adeg mincig jarang, jangkungilo, incek miring, cikalong angka delapan, klepat dua tangan, nindak tiga miring, ngayun jarang tangan satu, dan di akhiri dengan kode tanjak.

Pada ragam gerak unggah tengahterdapat 7 ragam gerak sebagai bagian lanjutan dari bagian dodoan yang terdiri dari gedig, capang banting tangan, jangkungilo maju, pakbang ngayun tangan dua, incek meneng banting tangan, sepak soder, adu bapa, dan nindak ambil kedok. Pada bagian deder/kering tiluterdapat 14 ragam gerak yakni capang bawa kedok, incek meneng bawa kedok, puter ules, incek meneng ukel ules,banting tangan tumpang tali, pakbang maju mundur, incek miring 2, incek jalan, tumpang tali kanan kiri, ngayun tangan dua, pakbang gede, ayun tangan satu, ngincig soder, dan hormat buka kedok.

\section{Musik/iringan}

Topeng Cirebon pada umumnya menggunakan gamelan berlaras slendro, namun tak jarang yang menggunakan laras pelog. Di Cirebon, gamelan yang berlaras slendro, yakni gamelan yang bernotasi paling tinggi, setiap tarian 
topeng Cirebon baik dalam pertunjukan topeng hajatan/dinaan mempunyai tingkatan irama yang sama. Kelima tarian topeng mempunyai struktur irama yang sama dan dalam setiap tarian terdiri atas beberapa lagu sebagai pengiringnya. Tarian Topeng Cirebon diiringi oleh beberapa lagu yang merupakan rangkaian utuh dan menjadi satu iringan. Iringan tari topeng tumenggung terdiri dari bagian dodoan (irama lambat), bagian unggah tengah (irama sedang/sawilet), dan deder (irama cepat/kering tilu).

Iringan masing-masing Tari Topeng Cirebon antara lain : 1) Tarian Topeng Panji diiringi oleh lagu Kembang Sungsang, Lontang Besar, Oet-oetan dan Singa Kawung; 2) Tari Topeng Samba diiringi oleh lagu Singa Kawung, Pacul Goang dan Sungsang serta Lontang Besar; 3) Tari Topeng Rumyang diiringi oleh lagu Kembang Kapas dan Samarangan Buncis; 4) Tari Topeng Tumenggung diiringi oleh lagu Kadipatenan atau Tumenggungan, Waledan dan Barlen; 5) Tari Topeng Klana diiringi oleh lagu Gonjing.

Tari Topeng Tumenggung Gaya Slangit Cirebon diiringi oleh lagu Tumenggungan (Dodoan), Waledan (Unggah Tengah) dan Barlen (Deder/Kering tilu). Alat musik yang digunakan dalam tari Topeng Tumenggung Gaya Slangit terdiri dari Bonang, Kendang, Saron I, Saron II, Penerus, Kenong, Gong, Kecrek, Suling, Kebluk dan Tutukan.

\section{Tata Rias dan Busana}

Tata rias dalam pertunjukan Tari Topeng Tumenggung Gaya Slangit Cirebon juga diperlukan meskipun penari memakai kedok atau topeng dalam menari. Tata rias dalam pertunjukan Tari Topeng Tumenggung Gaya Slangit Cirebon berfungsi untuk merubah karakter pribadi menjadi karakter tokoh/peran yang dibawakan yaitu tokoh tumenggung, untuk memperkuat ekspresi, dan untuk menambah daya tarik penampilan. Tata rias dalam Tari Topeng Tumenggung Gaya Slangit Cirebon menggunakan rias korektif.

Tata busana Tari Topeng Tumenggung Gaya Slangit sedikit berbeda dengan busana yang dipakai Tari Panji, Samba, Rumyang dan Tari Topeng Klana. Tari Topeng Tumenggung Gaya Slangit Cirebon pada awalnya muncul dengan busana yang khas pada penutup kepala yang disebut tekes (sobrah/gambuh) yang dapat dilihat pada Foto 1 busana awal Tari Topeng Tumenggung Gaya Slangit.

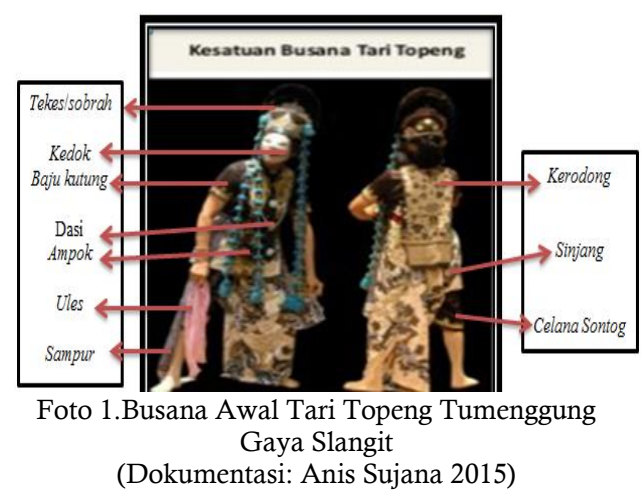

Foto 1 menunjukkan awal mula busana dan atribut Tari Topeng Tumenggung Gaya Slangit Cirebon yang terdiri dari tekes atau sobrah, kedok, baju kutungberwarna hitam, celana sontog berwarna hitam, keris, kewer, dan sampur.

Tari Topeng Cirebon awalnya hanya memakai bajukutung dan celanasontog berwarna hitam pada Tari Topeng Panji, Tari Topeng Samba, Tari Topeng Rumyang, Tari Topeng Tumenggung dan Tari Topeng Klana, yang membedakan kelima Tari Topeng Cirebon hanya pada topeng/kedok, namun seiring berkembangnya zaman para pengrajin membuat warna busana yang berbeda untuk masing-masing karakter dalam Tari Topeng Cirebon.

Tari Topeng Panji mengunakan busana dominan warna putih, Tari Topeng Samba dominan warna kuning, Tari Topeng Rumyang dominan warna hijau, Tari Topeng Tumenggung dominan warna hitam dan Tari Topeng Klana dominan warna merah pada pertunjukan Tari Topeng Cirebon.

Busana Tari Topeng Tumenggung Gaya Slangit Cirebon terdapat perubahan seiring berkembangnya zaman. Busana yang saat ini banyak digunakan masyarakat oleh masyarakat Cirebon dalam menarikan Tari Topeng 
Tumenggung Gaya Slangit Cirebon terlihat pada foto 2.Busana Tari Topeng Tumenggung Gaya Slangit Cirebon.

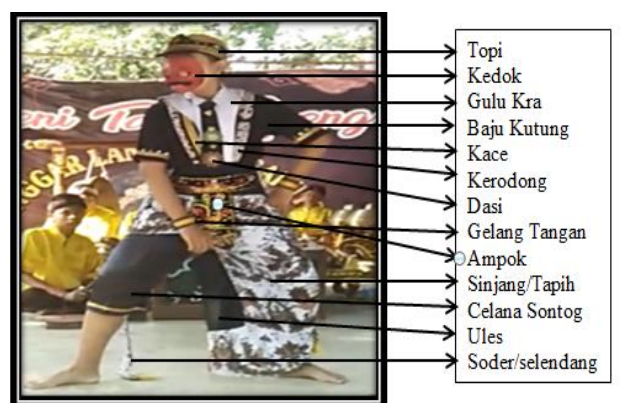

Foto 2. Busana Tari Topeng Tumenggung Gaya Slangit Cirebon

(Sumber: Nur Indah Hidayani, 23 September 2017)

Foto 2 menunjukkan busana penari Tari Topeng Tumenggung Gaya Slangit Cirebon. Foto 2 menunjukkan penari memakai kostum yang terdiri dari topi, kedok/topeng, dasi, gulu kra, kace, kerodong, baju kutung, celana sontog, ampok, sinjang, gelang tangan, ules, soder/selendang (wawancara, Sanija Wijaya 24 September 2017).

Material yang digunakan untuk busana dalam Tari Topeng Tumenggung Gaya Slangit Cirebon adalah kain batik. Dalam tradisi lama, penanggap topeng bisanya menyediakan beberapa helai kain batik (sinjang atau tapih dan selendang batik bermotif lokcan) yang kemudian dipakai dalam busana Tari Topeng Cirebon.

\section{Properti}

Tari Topeng Cirebon memiliki properti yang khas yakni adanya kotak topeng. Kotak topeng merupakan tempat menyimpan topeng ketika menari sebelum topeng dipakai. Kotak topeng mempunyai peranan yang sangat penting karena ketika pertunjukan berlangsung kotak topeng difungsikan untuk menyimpan beberapa perlengkapan pertunjukan, antara lain kedok-kedok yang akan ditarikan, kostum nayaga dan bodor, serta alat tabuh gamelan. Sebelum ada kendaraan roda empat (mobil) kotak topeng dan gamelan dibawa dengan menggunakan gotrok (pedati), yakni semacam gerobak yang ditarik oleh sapi atau kerbau.

Kotak topeng juga bermakna sebagai pusat pamiangan dan pengbalikan (pergi dan pulang) yang menjadi penyebab penari Topeng Cirebon selalu mulai menari dari depan kotak dan berakhir di depan kotak. Penutup kotak topeng tidak boleh dibuka sebelum penampilan Tari Topeng Cirebon dimulai, namun ketika penampilan Tari Topeng Cirebon dimulai penutup kotak topeng wajib dibuka.

Properti yang digunakan penari dalam Tari Topeng Tumenggung Gaya Slangit yakni berupa kedok, ules dan kacamata. Kedok dan ules merupakan properti yang wajib ada dalam pertunjukan Tari Topeng Tumenggung Gaya Slangit Cirebon, sedangkan pemakaian kacamata dalam Tari Topeng Tumenggung Gaya Slangit Cirebon boleh digunakan, boleh juga tidak digunakan yang dijabarkan sebagai berikut (wawancara, Sanija Wijaya 24 September 2017).

Kedok atau topeng merupakan properti yang wajib ada dalam setiap pertunjukan Tari Topeng Cirebon, salah satunya Tari Topeng Tumenggung Gaya Slangit Cirebon. Kedok yang dipakai dalam Tari Topeng Cirebon biasanya terbuat dari kayu yang dibentuk menyerupai wajah dengan memberi warna kedok yang sesuai untuk memperindah karakter dari kelima Tari Topeng Cirebon, sehingga karakter antara satu dengan yang lain berbeda. Ukuran kedok atau topeng yang dipakai dalam Tari Topeng Cirebon mengikuti ukuran wajah manusia.

Kedok merupakan salah satu ciri yang paling bisa diamati untuk melihat karakterisasi tari. Kedok atau topeng yang dipakai penari dalam pertunjukkan Tari Topeng Tumenggung Gaya Slangit Cirebon yang peneliti teliti berwarna merah. Cara pemakaian kedok yaitu dengan menggigit bagian yang berbentuk persegi panjang yang ada di bagian dalam kedok/topeng. Kedok atau topeng Tumenggung menyiratkan seseorang yang pemberani dan berwibawa. Bentuk kedok atau topeng Tari Topeng Tumenggung Gaya Slangit Cirebon yakni 
pada bagian matanya agak melotot, berkumis, dan berjambang.

Ules merupakan kain penutup topeng sebelum penari memakai topeng.Warna ules biasanya disesuaikan dengan warna baju penari. Ules berfungsi sebagai pembungkus topeng sebelum topeng digunakan oleh penari. Ules merupakan properti yang wajib ada dalam Tari Topeng Tumenggung Gaya Slangit Cirebon.

Kacamata merupakan properti yang dipakai dalam Tari Topeng Tumenggung Gaya Slangit Cirebon. Kacamata yang dipakai dalam pertunjukan Tari Topeng Tumenggung Gaya Slangit Cirebon memakai kacamata dengan kaca yang berwarna putih. Pemakaian kacamata dalam tari Topeng Tumenggung boleh dipakai boleh juga tidak dipakai. Berdasarkan hasil wawancara dengan Bapak Sanija Wijaya, beliau menjelaskan bahwa sebenarnya tidak ada pemakaian kacamata dalam Tari Topeng Tumenggung Gaya Slangit Cirebon.

Pemakaian kacamata dalam Tari Topeng Tumenggung pada generasi saat ini terjadi dikarenakan pelatih tari Topeng Tumenggung ketika melatih siswa-siswinya memakai kacamata sehingga generasi saat ini ketika menarikan tari Topeng Tumenggung memakai kacamata yang hanya sebagai tambahan dalam aksesoris busana, tidak dipakaipun tidak masalah.

\section{Pola Lantai}

Pola lantai Tari Topeng Tumenggung Gaya Slangit mengutamakan arah hadap ke penonton. Arah hadap penari Topeng gaya Slangit kepada penabuh gamelan juga dilakukan agar penabuh kendang dapat melihat gerakan penari dengan jelas. Pola lantai tari Topeng tumenggung tidak baku, artinya setiap penari bebas berkreasi dalam pola lantai ketika menari.

\section{Tempat Pentas}

Tempat pentas Tari Topeng Tumenggung Gaya Slangit Cirebon dapat ditampilkan secara indoor maupun outdoor dalam pertunjukan Tari Topeng Tumenggung Gaya Slangit Cirebon ditampilkan secara outdoor atau diluar ruangan di latar pendopo Sanggar Langgeng Saputra Desa Slangit Kabupaten Cirebon.

$\begin{array}{clr}\text { Analisis Gaya } & \text { Tari } & \text { Topeng } \\ \text { Tumenggung Slangit } & & \\ \text { Gaya Tari } & \text { Topeng } & \text { Cirebon } \\ \text { bermacam-macam tergantung dari }\end{array}$
individu masing-masing. Gaya individu biasanya dipengaruhi oleh interpretasi dan kreativitas individu serta postur atau wanda seseorang. Interpretasi seniman topeng terhadap karakter peran mempengaruhi kreativitas penari yang terlihat pada berbagai variasi gerak, serta susunan sajian tarinya. Postur atau wanda penari berpengaruh juga pada cara membawakan tarian, khususnya dalam pengolahan tenaga, ruang, dan waktu. Analisis gaya Tari Topeng Tumenggung Slangit Cirebon dapat diketahui dengan cara melihat pandangan pencipta atau seseorang yang mengetahui secara detail tentang Gaya Slangit dan penonton dengan melihat bentuk penyajian Tari Topeng Tumenggung Gaya Slangit Cirebon yang meliputi gerak, iringan, dan tata busana.

Perbedaan yang menonjol dari setiap gaya Tari Topeng Cirebon dapat dilihat melalui susunan penyajian tari. Susunan penyajian gaya Topeng Slangit mengacu pada tafsiran sifat manusia dari lahir hingga dewasa yang dimulai dari Tari Topeng Panji, Samba, Rumyang, Tumenggung dan Klana yang berbeda dengan susunan penyajian Tari Topeng Cirebon gaya Losari.

Susunan penyajian Tari Topeng Gaya Losari dimulai dengan Tari Topeng Samba yang memerankan Panji Sutawinangun, Kili Padukanata dan Patih Jayabadra, Tumenggung dan Jinggananom, serta Klana yang lebih mengacu kepada cerita Panji atau Jaka Bluwo daripada tafsiran susunan berdasarkan sifat manusia dari lahir hingga dewasa sehingga berbeda pula variasi geraknya.

Pengolahan ruang gerak tari dianggap baku pada tari Topeng Cirebon, akan tetapi susunan gerak dan variasinya memungkinkan penari berkreasi sendiri sehingga secara spontan susunan gerak 
terwujud di atas pentas. Susunan gerak dan variasi Tari Topeng Cirebon yang memungkinkan penari berkreasi sendiri membuat setiap penari mempunyai ciri khas yang berbeda satu sama lain.

Ciri khas yang terus berulang akhirnya menjadi ciri tampilan seorang penari pada daerah tertentu, seperti perbedaan yang mencolok antara gaya Tari Topeng Losari dengan gaya Tari Topeng Slangit ditinjau dari kelenturan badan penari. Gerak Tari Topeng Gaya Losari lebih lentur dibandingkan dengan Tari Topeng Gaya Slangit.

Perbedaan variasi gerak Tari Topeng Tumenggung Gaya Slangit Cirebon dengan Tari Topeng Tumenggung Gaya Losari juga terlihat pada salah satu ragam gerak sepak soder. Tari Topeng Tumenggung Gaya Slangit dan Gaya Losari pada keduanya samasama memiliki ragam gerak sepak soder, namun cara penari melakukan ragam gerak sepak soder pada Gaya Slangit dan Gaya Losari berbeda.

Ragam gerak Sepak Soder pada Tari Topeng Tumenggung Gaya Slangit dilakukan dengan cara menginjak soder/selendang menggunakan kaki, kemudian soder/selendang di buang ke belakang, sedangkan ragam gerak sepak soder Tari Topeng Tumenggung Gaya Losari dilakukan dengan menginjak soder/selendang kemudian dibuang ke depan.

Tata busana Tari Topeng Tumenggung Gaya Slangit memiliki perbedaan dengan busana Tari Topeng Tumenggung Gaya Losari.Tari Topeng Tumenggung Gaya Slangit menggunakan bendo/topi sebagai penutup kepala, kerodong yang hanya menutupi bagian belakang punggung penari, gulu kra, kace yang di kalungkan di leher berbentuk persegi panjang berwarna hitam, dasi, baju kutung berwarna hitam, ampokberwarna hitam, celana sontog berwarna hitam, ules berwarna hitam, sinjang/kain, kedok berwarna merah jambu yang berbeda dengan busana Tari Topeng Tumenggung Gaya Losari.

Tari Topeng Tumenggung Gaya Losari menggunakan ikat kepala sebagai penutup kepala, kerodong yang berbentuk setengah lingkaran sehingga menutupi bagian depan dada hingga bagian belakang punggung penari, baju kutung berwarna merah, celana sontog berwarna merah, apok leher yang dikalungkan di leher berbentuk setengah lingkaran berwarna merah, ules berwarna merah jambu, sinjang/ kain, dan kedok yang berwarna putih tanpa pemakaian gulu kra dan dasi seperti aksesoris yang di gunakan pada busana Tari Topeng Tumenggung Gaya Slangit.

\section{SIMPULAN}

Tari Topeng Tumenggung Gaya Slangit merupakan bentuk tarian keempat dalam Tari Topeng Cirebon Gaya Slangit yang mengisahkan sebuah kisah kecil dari cerita panji mengenai Tumenggung Magangdiraja yang diutus Raja Bawarna untuk mencari Jinggananom yang telah lama tidak membayar upeti, namun setelah bertemu Jinggananom menolak membayar upeti sehingga terjadilah perang. Analisis gaya Tari Topeng Tumenggung Slangit Cirebon dapat diketahui melalui bentuk penyajian dan analisis gaya.

Bentuk penyajian Tari Topeng Tumenggung Gaya Slangit Cirebon meliputi gerak yang terdiri dari 3 tahap yakni tahap Dodoan pada bagian awal penyajian, Unggah Tengah pada bagian tengah penyajian, Deder/Kering Tilu pada bagian akhir penyajian. Perpindahan gerak dari tahap awal sampai akhir diikuti dengan iringan musik yang juga terdiri dari tiga lagu yakni lagu Tumenggungan untuk mengiringi gerak pada tahap dodoan, lagu Waledan untuk mengiringi gerak pada tahap Unggah Tengah dan lagu Barlen untuk mengiringi gerak pada tahap Deder/Kering Tilu. Tata rias yang digunakan dalam pertunjukan Tari Topeng Tumenggung Gaya Slangit Cirebon yakni rias korektif serta busana yang menyerupai orang berstatus sosial tinggi yang dapat dilihat pada pemakaian dasi, topi, dan kalung. Properti yang digunakan pada pertunjukan Tari Topeng Tumenggung Gaya Slangit Cirebon yaitu kedok/topeng, ules dan kacamata. Pertunjukan Tari Topeng Tumenggung Gaya Slangit Cirebon ditarikan pada ruang terbuka, namun bisa juga di tarikan dalam ruang tertutup. 
Analisis gaya Tari Topeng Tumenggung Slangit Cirebon dapat dilihat setelah diketahui bentuk penyajian tarinya yang kemudian dikaitkan dengan interpretasi, kreativitas, dan postur/wanda ketika penari menarikan Tari Topeng Tumenggung Slangit Cirebon. Interpretasi penari saat menarikan Tari Topeng Tumenggung Gaya Slangit Cirebon kurang mendalami peran atau tokoh Tumenggung, jika dilihat dari segi kreativitas penari melakukan beberapa gerakan yang berbeda, dan postur penari dalam pengolahan tenaga, ruang, dan waktu masih banyak yang harus di perbaiki terutama pada pengolahan tenaga yang kurang tegas atau kurang kuat, serta pada pengolahan waktu yang tidak pas sehingga gerak penari sering mendahului iringan musik.

\section{DAFTAR PUSTAKA}

Jazuli, M. 2016. Peta Dunia Seni Tari. Sukoharjo: CV. Farishma Indonesia.

Kusumastuti, Eny, Hartono. 2017. "Kuda Debog Dance for Childrens Social Development". Jurnal Ponte. 73 (6) : 117.Diunduh di http://www.pontejournal.net/mainpa nel/abstract.php?TOKEN $=$ gRkgF541 $1 \mathrm{G} \& \mathrm{PID}=\mathrm{PJ}-52 \mathrm{HXO}$.

Masunah, Juju. 2000. Sawitri: Penari Topeng Losari. Yogyakarta.

Masunah, Juju dan Karwati, Uus. 2003. Topeng Cirebon. Bandung: P4ST UPI.

Miles, Matthew B, Huberman, A. Michael (Ed). 2007. Analisis Data Kualitatif. Jakarta: Universitas Indonesia.

Rohidi, 2011. Tjetjep Rohendi. Metodologi Penelitian Seni. Semarang: Cipta Prima Nusantara Semarang.

Sujana, Anis. 2015. "Kajian Visual Busana Tari Topeng Tumenggung Karya Satir Wong Bebarang Pada
Masa Kolonial".Jurnal Panggung. 25(2) : 1-13. Diunduh di https://jurnal.isbi.ac.id/index.php /panggung/article/viewFile/ 4/7 Happened after Jomtien? International Review of Education, 41(6), 537-549.

Soedarsono.1978. Pengantar Pengetahuan dan Komposisi Tari.Yogyakarta: ASTI. 